\title{
Reluctant Romantics - On the fairy tale poetics of the Brothers Grimm and their relationship to German Romanticism
}

Author:

Isabel dos Santos

Affiliation:

${ }^{1}$ Department of Modern Foreign Languages,

Stellenbosch University,

South Africa

Correspondence to:

Isabel dos Santos

Email:

icds@sun.ac.za

Postal address:

Private Bag X1, Matieland

7602 , South Africa

Dates:

Received: 05 Aug. 2013

Accepted: 19 June 2014

Published: 03 Dec. 2014

How to cite this article:

Dos Santos, I., 2014,

'Reluctant Romantics - On the fairy tale poetics of the Brothers Grimm and their relationship to German Romanticism', Literator 35(1), Art. \#1073, 8 pages. http://dx.doi.org/10.4102/lit. v35i1.1073

\section{Copyright:}

(C) 2014. The Authors.

Licensee: AOSIS

OpenJournals. This work

is licensed under the

Creative Commons

Attribution License.
The legacy of the Brothers Grimm continues to fascinate readers and researchers alike. The 200-year anniversary of the first publication of their fairy tales sparked a renewed interest in the life, work and times of the brothers. Fascinated by the past, by the political present and by the literary future of Romanticism, the Brothers Grimm stayed together in an unusual working union. They established what was to become German philology and published many invaluable works on language and history, myths and folk tales. This article will focus on the brothers' place in German Romanticism through their contribution of fairy tales. The period was marked by political and philosophical thought that emphasised authentic experienced and the spiritual unity of art, science and philosophy. There was a strong call for national emancipation. Literature was required to embody this unity through an established national literature founded on German folk traditions. The Grimms seemed to have heeded that call. But a careful study reveals that their intentions were motivated less by the literary movement than by their own strong convictions which they upheld even at the cost of compromising the authenticity they claimed to uphold in their poetics. The many controversies regarding the origins, collection and editing of the fairy tales is inextricably linked to the brothers' difficult relationship with the Romantic Movement. Two hundred years later, this article seeks to give an appraisal of the Brothers' motivation for their poetics and of the research conducted thus far.

Teensinnige Romantici - Oor die sprokiesopvattings van die gebroeders Grimm en hulle verhouding tot die Duitse Romantiek. Die nalatenskap van die gebroeders Grimm fassineer lesers en navorsers nog steeds. Die 200-jarige herdenking van die eerste publikasie van hulle sprokies het nuwe belangstelling in die lewe, werk en tydsomstandighede van die Grimms gewek. Betower deur die verlede, die politieke hede en die letterkundige toekoms van die Romantiek, het hulle op 'n ongewone manier saamgewerk om wat uiteindelik Duitse filologie sou word, te vestig. Hulle het talle waardevolle werke oor taal, geskiedenis, mites en volksverhale gepubliseer, waaronder hulle versamelings wêreldberoemde feëverhale. Hierdie artikel fokus op die broers se posisie binne die Duitse Romatiek en die bydrae wat hulle gemaak het in die vorm van sprokies. Die tydperk is gekenmerk deur politieke en filosofiese denke, wat outentieke ervaring en die spirituele eenheid van kuns, wetenskap en filosofie nagestreef het. Nasionale emansipasie was aan die orde. Letterkunde moes sodanige eenheid beliggaam deur 'n nasionale letterkunde wat geskoei is op Duitse volkstradisies. Dit lyk asof die Grimms 'n belangrike bydrae hiertoe kon lewer. Noukeurige navorsing toon egter dat hulle intensies deur hulle eie sterk oortuigings gemotiveer is, eerder as deur die literêre beweging. So sterk was hulle eie oortuigings dat dit selfs die outentisiteit wat hulle voorgee om te handhaaf in hulle werk, onder verdenking plaas. Die talle geskille ten opsigte van die oorsprong, insameling en redigering van die sprokies is onlosmaaklik verbind aan die broers se problemantiese verhouding met die Romantiese Beweging. Hierdie artikel gee 'n oorsig van die motivering agter die broers se opvattings en van die onlangs navorsing oor hulle werk.

\section{Point of departure}

Jacob and Wilhelm Grimm published the first edition of their Children and Household Tales (Kinderund Hausmärchen) in December 1812. The 200-year anniversary was duly celebrated and 2013 officially proclaimed Grimm Year. Scholars had the opportunity to gather in order to compare and update current research trends. ${ }^{1}$ The oeuvre of the Brothers Grimm has become monumental and has far exceeded the borders of Germany and of Europe, of Philology and Literature studies.

\footnotetext{
1. Apart from investigations into fairy tales, topics such as their international reception, translations and cultural shading, methodology and reinterpretations where the old texts serve modern times, as in the topical debate on male identity, were discussed in academic circles. One of the main conferences in Germany was the international congress in Kassel Märchen, Mythen und Moderne in December 2012. See the full program at http://www.grimm2013.de
} 
The fairy tales especially assured the brothers' immortality. Throughout the entire world, fairy tales have for generations played a significant part in children's upbringing and in human consciousness. They teach about life and death, solitude and social skills, forgiveness and endurance. Their characters and themes have been reworked in literature and the media in different ways and in countless interpretations; currently there is a veritable renaissance of fairy tales in the film industry. ${ }^{2}$ Their language has influenced German philology to an extent that few other German literary works can boast; after the Luther Bible, the Grimm fairy tales are the most translated German book (Ewers 2012).

The Grimms' legacy extends far beyond their world-famous fairy tales. The brothers explored myths, old narrative materials such as legends and farces, animal and heroic epics of archaic cultures and times long past. Many of these stories still hold their fascination today, as do the opinions the brothers held on how the ancient narrative materials should be dealt with - still a topical and controversial discussion. They developed techniques that are still held in regard nowadays and excelled as researchers, editors, myth discoverers, language historians, dialecticians and as writers of a comprehensive German dictionary. Hailed as the forefathers of German philology, they were equally committed to and respected for their political engagement. Their search for knowledge, their political convictions and their endeavours to edify the people mark them as products of their time: the age of Romanticism.

Having been born into the upheaval of what was to become German Nationalism, their contribution to German Romanticism was a daring one: trying to preserve the old, they forged the new, and did not shy away from taking a stand against others. Whilst the poetics of most Romantics allowed a great deal of personal input from the artist, so that even new creations could be labelled 'folk literature', the Grimms' primary concern was to remain true to the originals they studied and researched. For the brothers, history and poetry were linked in an inseparable unit, which must be preserved and rendered untouched. This standpoint they defended throughout their lives and led to the creation of their own poetic artistry. They fought openly against their peers' viewpoints, making them more rebels than Romantics. Even so, German Romanticism as it is understood today would be unthinkable without the Brothers Grimm.

The invaluable contribution they made to this over 200-year-old cultural movement - and which has inspired German thinkers to this day - is nonetheless marked by as many controversies as successes. Whilst they stood by their methods and are considered pioneers owing to many innovative techniques, especially as collectors and folklore researchers, the editorial principles they upheld are considered tarnished today. One of the most popular

2.In 2012, Hollywood saw no fewer than three new adaptations of Snow White alone on cinema screens, with another Spanish version rated best foreign film at international film festivals: Snow White and the Huntsman by Rupert Sanders, Mirror Mirror by Tarsem Singh, Grimm's Snow White by Rachel Goldenberg and Mirror Mirror by Tarsem Sing
Biancanieves by Pablo Berger. misconceptions to date is that the Grimms' fairy tales were true German folk tales, collected from amongst the common people and suitable as children's literature. This article will show that the Grimms had little regard for the ideals of Romanticism, and although their poetics shared similarities with contemporary writers their use of the fairy tales was not entirely genuine or accidental but rather ingeniously orchestrated. Setting themselves apart from the literary programme of the Romantic Movement whilst embracing its core political values, the Grimms devised their own poetic approach: claiming to render true, original folk tales they hid both their true sources and their true origins. Another important aspect of Romanticism and of the Grimms' poetics was to appeal to the childlike innocence of the soul. The assumption of a long forgotten 'childhood of humankind' was a popular thought amongst Romantics. The Grimms would adopt this, and claim that their fairy tales were suitable for children. This article will thus argue that, although the Grimm brothers are considered part of the Romantic Movement, their relationship with German Romanticism was problematic.

\section{Romanticism and the Grimms}

Although Romanticism was the dominant movement of the late 18th century and early 19th century, in Germany it developed relatively late compared to other European countries. Whereas English Romanticism is dated as early as the 1770s, the first phase of German Romanticism commenced more than 20 years thereafter. German literary history (Mende 2002) divides its Romantic period (ca. 1798-1835) into three distinct phases: early Romanticism (ca. 1798-1804, established in Jena), high Romanticism (ca. 1804-1818, established in Heidelberg) and late Romanticism (ca. 1816-1835, established in Berlin). The distinction is based not only on the dates and on geography, but is primarily made according to the different viewpoints held by the groups of writers. The Grimm brothers' contributions fall into the middle phase. Whilst early Romanticism focused on the unity of man and nature, and late Romanticism on the tensions between the mundane world and seemingly irrational and supernatural projections of the creative genius, Romantics in high Romanticism concentrated on the edification of the people and on the unity of nation and country, especially after the Holy Roman Empire was dissolved in the Napoleonic Wars (Mende 2002; Rothmann 1987).

Although it can be argued that high Romanticism is the politically more pronounced phase, German Romantics in all three phases encouraged a revolutionary and philosophical stance: instead of embracing the rational and logical beliefs encouraged by the Age of Enlightenment (ca. 1720-1790), a focus on sensations and the irrational was sought, with great emphasis on intense and authentic experiences in nature, in love and in knowledge. In fostering a sense of spiritual unity, much regard was given to the search for identity and to the protagonist who suffers the contradictions between the cult of individuality and the longing for community. By looking 
at the Middle Ages as a simpler, more integrated period, the Romantics tried to create a new synthesis of art, philosophy and science (Stephan 2008). These fundamental ideas are considered the core of German Romanticism, although an emphasis is placed on a different mode of thought in each of the three Romantic phases as mentioned above.

The movement was not only a literary but also an artistic, philosophical and, to a certain degree, ${ }^{3}$ a political expression. It is, however, the literature component that is most relevant for the present argument. The Grimms did not consider themselves part of the Romantic Movement (Rothmann 1987). Their preoccupation lay with ancient texts which they sought to preserve for posterity, not with philosophical thought or poetic artistry. Their association with the Romantic Movement can be regarded as almost by chance, due rather to their political opinion and their passion for ancient folklore than to their following the Romantic literary programme. In their student days, when they discovered their love for ancient writings, they admired Ludwig Tieck and followed the 'new school' of the brothers August Wilhelm and Friedrich Schlegel. The Schlegels lived in Jena and shared their ideas with like-minded colleagues such as Tieck, Schleiermacher and Novalis. They started the first of the three distinct periods of German Romanticism: Jena or early Romanticism. Their publication Athenäum (1798-1800) was the leading mouthpiece for the phase and featured mostly literary fragments; this was particularly well suited to early Romanticism, since it embraced incompleteness as a major art form (Schlegel 1798). Here, Friedrich Schlegel (1798) gave his famous definition of Romantic poetry as a 'progressive universal poetry' ${ }^{4}$ that combined and reunited all different genres, mixed poetry with philosophy and rhetoric, with nature and art:

Romantic poetry wants and ought to combine poetry and prose, genius and criticism, art poetry and nature poetry, mixing it, fusing it. It should make poetry lively and sociable, and make life and society poetic. It should poeticise wit and fill all art forms with sound subject matter of every kind to form and satisfy the human soul, to animate it with flights of humour. Romantic poetry embraces everything that is purely poetic, from the greatest systems of art, which contain within them still more systems, to the sigh, the kiss, breathed out by a poeticizing child in an artless song. (p. 116)

This definition was groundbreaking and determined the (albeit vague) course of the literature of the day. However, the interest of the Grimms was not focused on the philosophical programme of romantic poetry but rather on the political undertone of the group's writing, calling for a new order through the identity of state and people: a national identity forged by a common idiom, as Jacob Grimm envisaged it (Rothmann 1987). His vision would lay the ground rules for times to come. A change of perspective was sought by the writers of the Athenäum as well as the Grimms: the ideals of antiquity, of Rome and Greece, must give way

3.Whilst most Romantics avidly discussed politics and longed for a freed and unified nation in their writings, very few actually became politically active. The Grimms were two of the few exceptions. See also FN6.

4.All quotations were translated by me from the original German. to the new ideals of European states, starting with a unified language. How close this ideal of a national philology was connected to the political aim of creating nation states, and the consequences of these developments, probably no one could fully realise at the time.

Neighbouring France had had a revolution, an occurrence most German scholars and artists had welcomed, but their enthusiasm was soon replaced by horror and disgust. From 1794 French troops began occupying the territories of the German Empire west of the Rhine, annexing entire cities and bringing its people much hardship. The Holy Roman Empire of the German nation, after an existence of almost 1000 years, was dissolved in 1806 by Emperor Franz II following an ultimatum by Napoleon. In the same year, Hesse also fell to the French and with it its capital Kassel, where the Brothers Grimm lived (Rothmann 1987). The longing for a free, united Germany intensified as the living conditions kept on deteriorating. German thinkers and poets turned away from the country that they had looked up to as their example of choice for culture and refinement, and searched within themselves. A national crisis is the best basis for the creation of national unity and this is found in no place better than its Volk, its people and their stories: the poor, the downtrodden, the dreamers, the ones who know hardship first and adapt the quickest. Whilst up to this time the Germanic culture had been disregarded, as barbaric, by the French, it was now turned to as an alternative.

The Grimms' research and preservation of the German cultural heritage was therefore also a political act. Not only did they aim at exploring and understanding the cultural tradition, they also wanted to make it available and understandable to the wider public; in doing so they hoped to lay a foundation for a modern nation state, fulfilling a prerequisite for this paradigm (Rothmann 1987). Whereas the early Romantics had concentrated on their philosophical programme and created art for their own edification, the high Romantics strove to educate the masses through their literature; they considered this a national duty (Van Rinsum \& Van Rinsum 1987). The Brothers Grimm could identify with this principle. They differed from their peers in that these believed that such a literature must come from history as well as from poetry, whilst the brothers embraced history but rejected any 'fake' art form (Rothmann 1987). Far from following the Romantic art programme, their intention had little to do with the poetic ideals of the Schlegels and other Romantics. Poetic creations were not interesting to the Grimms. In fairy tales, legends and folk songs the brothers found a treasure of the last remnants of what they called natural poetry, seemingly long forgotten. They searched for the essence of this 'nature poetry', calling it also epic poetry, national poetry or folk poetry. The division between poetry and history had not yet taken place in the early times, Jacob reasoned, both 'flowing in the same river. If Homer of the Greeks is rightly praised as the father of history, we must no longer doubt that the first glory of German history has been lying hidden in the Nibelungen. ... Deeds and stories must speak as one voice, which echoes and resonates through its 
entire people' (Grimm [1808] 1985). By setting nature poetry (naturpoesie) apart from art poetry (kunstpoesie), the Grimms picked up an old debate from 17th-century France about the relation of contemporary art to culture and the traditions of antiquity. This debate flared up in Germany only around 1790, owing to Friedrich Schiller's and the Schlegel brothers' writings, and dominated the self-reflection of the German writers and thinkers (Bunzel 2010). Imperative for the Grimms in the discussion were the criteria of literacy and orality, which they used to determine the dominance of either nature or art in poetry.

Although considered part of the group of prominent authors of the Heidelberg or high Romanticism - such as Achim von Arnim, his later wife Bettina and her brother Clemens Brentano, with whom they collaborated on the famous anthology Des Knaben Wunderhorn - the Grimms' views differed in many ways from their Romantic peers'. In a letter from 17 May 1809 Jacob complains to his brother that 'they have no interest in a historic accurate investigation', that the old is not left as such but 'uprooted and replanted in modern times, where it must wither and die' as the glory of the old poetry, Jacob claims, must be enjoyed through its history and cannot survive solely as poetry (Grimm 1809). Unlike their colleagues who adapted the old stories to suit the requirements of their times and submitted them to what they considered 'art' according to the ideals of Romanticism, the Grimms sought 'true' poetry and remained faithful to it as far as they could, trying 'not to add, embellish or alter any significant facts or circumstances' (Grimm \& Grimm 1812).

Many Romantics presumed the origins of German history lay in Nordic mythology. The themes of magic in the texts suited the Romantics well and the old virtues such as loyalty, courage and endurance gained a new, powerful appeal and embodied the patriotic desire to get back on one's own feet politically. But most authors argued that the old tales had to be reworked in order to achieve the desired effect. Ludwig Tieck's version of Puss in boots from 1797 was an example of that, and Clemens Brentano went as far as writing about an 'old German legend' which he had unscrupulously created himself: the story of the bewitching Loreley, who sat above the Rhine and whose song and beauty led men to their demise, was pure invention on Brentano's part. However, the tale was so well told that a quarter of a century later Heinrich Heine assured its survival: his melancholic poem about the 'fairy tale of ancient times' put to Friedrich Silcher's bewitchingly melodic music was to become one of Germany's most beloved folk songs.

The Grimms did not believe in such creations and openly classified them as a 'forgery of German values' (Rothmann 1987:145). Theirs was an empirical, detail-focused methodology aimed at bringing an accurate past to life by remaining true to the original storylines, even if they had to select or combine different versions of similar tales. Poetry for the Grimms was intrinsically associated with themes of mythology and history, themes they collected, researched and meticulously classified, as this was the only way they knew to 'penetrate the inner essence of the history of poetry' (Grimm 1809). They clearly differentiated between the themes and motifs in the fairy tales, which they claimed to obtain from oral tradition, and the narrative form of the fairy tales, which they themselves provided as writers. Their Romantic engagement was thus more in their attitude than in an outspoken commitment to the movement. Similarly, biographer Steffen Martus considers them to be 'modern traditionalists' whose gaze was directed at the past although their attitude belonged entirely to the present (Martus 2009). With their own stand on poetics - Romantic or not - they fought for their interests and beliefs. But by wanting to uphold the true oral tradition, their sources had to come from the people - an aspect that proved problematic, as investigations have shown.

\section{Fairy tales about the fairy tales}

Despite their intended accuracy as scientists and historians, not all about the Grimms' methods is as it seems. For a long time researchers and scholars of fairy tales believed that the brothers collected the fairy tales by listening to the Volk, travelling through the countryside in search of different versions and adaptations handed down through oral traditions. This rather romantic notion served the times well but does not quite correspond to the truth, and more recent findings prove it to be 'the greatest fairy tale of them all' (Ewers 2012).

This is not to say that the brothers lied or falsified their sources. They were careful to formulate the origins in such a way as to create the idea that the fairy tales had been collected from amongst the simple people in their own environments, thereby being true folk tales suited to the Romantic ideals of the time. The real identities of the storytellers remained a mystery, and it was believed the tales came from old peasant women such as the Märchenfrau Dorothea Viehmann, as depicted in Louis Katzenstein's painting ‘The Brothers Grimm at the home of the Märchenfrau', where the brothers are seen listening and writing surrounded by small children and farm animals in a homely country kitchen idyll (see Figure 1).

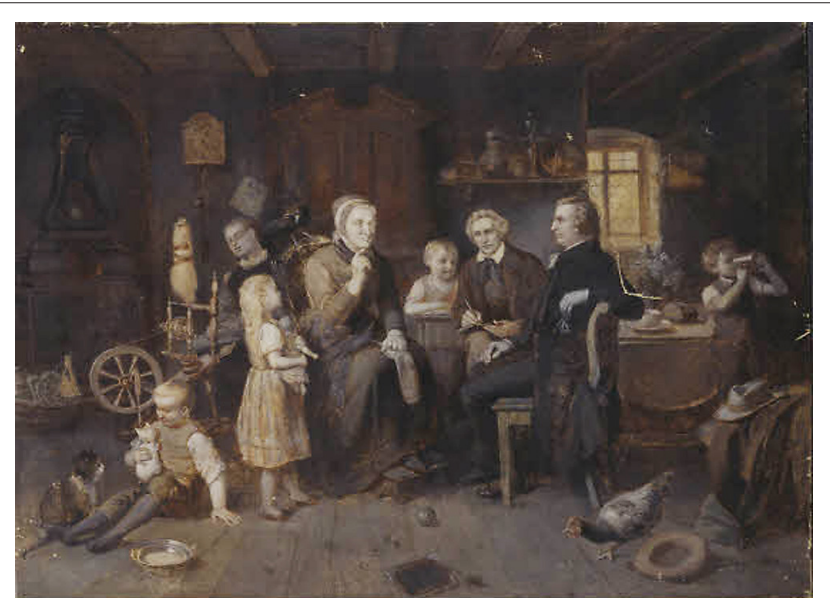

Source: (C) Museumslandschaft Hessen Kassel; bpk.

FIGURE 1: Die Brüder Grimm bei der Märchenfrau by Louis Katzenstein. 
The fairy tales were never conveyed in such a way. They were retold by literate bourgeois ladies who were invited into the brothers' studio in the city and who were often paid for their services (Rölleke 2011). Rölleke (2011) dedicated a meticulous study to 'who told which fairy tale', coming to very impressive, detailed conclusions. Apart from Dorothea Viehmann, who was not a poor peasant but a well-todo business woman from Kassel, Rölleke lists the poet Annette von Droste-Hülshoff and her sister Jenny, Marie Hassenpflug and her two sisters Amalie and Jeanette, and about 20 other storytellers, mostly young unmarried women of higher upbringing, but also educated men. The notes that the brothers kept reveal that these identities were protected (Rölleke 2011), maybe because the brothers demanded it but more likely still because the storytellers preferred it. Being associated with the rather disreputable genre of fairy tales was at the time not something a cultured young lady or gentleman would like to make public knowledge. ${ }^{5}$ Albeit speculative, one must consider that these meetings probably took place under great secrecy, as the Grimms claimed their sources came from the Volk. With the exception of Viehmann, whose name was revealed although her true identity was altered from business woman to peasant, the Grimms guarded their secret sources and defended their stance on oral tradition until the end of their days. So only the name and likeness of Dorothea Viehmann adorns the second edition of the tales, cited as their source and as representative of the collective.

Only in the final years of the 20th century did the true oral sources start to surface. The research was challenging as many mistakes became apparent due to the secretive nature of the original documents. The Grimms noted only the first names of their sources, so that it took much investigation to find out that 'Marie', for example, was not, as previously supposed, the nanny of the Wild family who owned the pharmacy in Kassel but rather the much younger Marie Hassenpflug whose family had been friends with the Grimms since before their birth and who also lived in the city. Until then, two-thirds of the fairy tales had been erroneously attributed to the nanny 'Old Marie', overlooking various other female members of the Wild family, including Wilhelm's wife-to-be Dorothea Wild. Corroborating the new discovery was the tone and the motives of the tales, which were so much more suited to the lifestyle and experiences of a young, upper-class woman - a fact both overlooked and wondered at before (Rölleke 2011).

Indeed it seems reasonable to admit that the cultured Marie Hassenpflug must have had quite a different repertoire of fairy tales than the illiterate nanny might have possessed. But research shows that most of the fairy tales can really be attributed to Marie and her two sisters, whose family were Huguenot immigrants on the mother's side. Rölleke argues that the three girls must have had a thoroughly French upbringing and thus the fairy tales they had retold to the Grimms were in essence 'not German at all' but French beginning to be asserted. See also, for example, Zipes (2012).
(Rölleke 2012:41). Having had no maternal grandmother, they heard the tales in their childhood from their Frencheducated mother, who had been brought up by her grandmother in her French household. This might explain the great affinity of some tales to entire passages of Charles Perrault's versions. Some critics suggest that the supposedly German tales were marked by influences of the rich French and Italian fairy tale tradition of the 17th century and 18th century centuries on various levels and that the Grimms could not disclose this if they wished to promote their collection as 'genuinely German' tales. Also the Grimms' 'true Hessian peasant woman' Dorothea Viehmann was later identified as a descendant of French Huguenots. Whether this was known to the brothers has not yet been established with certainty, but in Rölleke's opinion it is more likely than not (Rölleke 2012). Viehmann's contribution of about 40 fairy tales was only taken up in the second edition (1819). When the first edition was published 1812 she was yet unknown to the Grimm brothers. Nevertheless, she was to be the closest example they had of the folk in town and country, and was to become famous as their Märchenfrau par excellence. Some fairy tales of the Hassenpflugs of the first edition were taken out (Puss in Boots and Bluebeard allegedly had a 'foreign' ring to them and were removed) and replaced by 'true Hessian' versions retold by the talented Viehmann.

The fairy tales were thus not really taken from the people to the people, neither in their sources nor in their style. Having analysed the language of the tales, Ewers (2012:58) states that the fairy tales are not true folk tales; they are a literary work of art'. Could this mean that the Grimm brothers' integrity was questionable - that they accused their Romantic colleagues of failing to remain true to history and thereby destroying the essence of the fairy tale when they themselves tried to fool their audiences? The matter is not quite that simple, as Ewers explains. Basing his interpretation on the studies of Walter Berendsohn from 1921 - the first to voice the discrepancy between intended folk tradition and literary art in the Grimms' work - it would not have been possible to do justice to history and science by rendering the oral narrations in the same way they were told (Ewers 2012). Berendsohn speaks of the 'loving devotion' the brothers had for their subject matter (Ewers 2012). But in order to preserve the tales and old stories through literature, the Grimms had to devise their own poetics. The divide between oral tradition and literary art form was too wide if scientific research was to be the point of departure. Oral tradition was an insufficient scientific basis for the Kinder- und Hausmärchen; it had to be backed up. The brothers worked systematically: Jacob's preoccupation lay in maintaining the tales' originality and giving the recordings a scientific basis whilst Wilhelm gave them his own characteristic narrative style. It is this peculiar narrative style that gives the tales their unique linguistic character, which has become so loved in fairy tale culture. However, to go as far as to equate the Kinder- und Hausmärchen with other Romantics' artistic poetry, such as the Kunstmärchen by Brentano, von Arnim, de la Motte Fouqué, Hoffmann or von Eichendorff, would be a great injustice to the Grimms' work. Ewers agrees 
with Berendsohn in that the Grimms' fairy tales should be understood as one specific kind of literary art of the period and should neither be categorised as Kunstdichtung nor as Volkserzählung. Literature and folklore are fused in a unique type of poetics. To 'add, embellish or alter' (Grimm \& Grimm 1812) the narrative became necessary if the texts were to be taken seriously and to survive. Respect for the essence of the tradition was nevertheless maintained as a genuine concern. Living in tumultuous times, the brothers were acutely aware that the German legacy inherent in the old stories would soon disappear forever if not captured and preserved through the well-written word.

\section{Literature for children}

Ewers (2012) criticises the Grimms for purposely discrediting the older European fairy tale tradition (especially of Italy and France in the 17th century and 18th century) to advance their own 'pioneering' cause and thereby ignoring an entire period. By the time the Grimms started their collection, the French had already institutionalised the literary fairy tale as an aesthetic and social means of literary socialisation. As Jack Zipes (1999) points out, the established fairy tale tradition in Europe played a significant role in cultured circles:

A conte de fée, based on the oral Zaubermärchen, was ... a literary genre that addressed the concerns, tastes, and functions of court society. The fairy tale had to fit into the French salons, parlors, and courts of the aristocracy and bourgeoisie if it was to establish itself as a genre. ... Two Italian writers, Giovanni Francesco Straparola and Giambattista Basile, had already set an example for what the French were accomplishing. (n.p.)

Much of the Grimm's own repertoire was based on wellestablished tales that respected and served the upholding of aristocratic and bourgeois ideals. Apart from expressing basic political views of the Enlightenment, the recurring theme in these tales was the pursuit of ideal love, in which erotic and sexual subject matter was not shunned. The Grimms' 1812 fairy tale collection was purposefully called 'children and household tales', indicating its suitability for family reading and bourgeois leisure time. An important aspect of the Grimms' poetics was to show the childlike innocence of the fairy tale - going back to the times where the soul of humankind was thought to be new, guileless and pure. This assumption of an ancient 'childhood of humankind' and a still-existent childlike human spirit (found in children, dreamers, artists, mothers or the mentally challenged) had been formulated by Johann Gottfried Herder ([1773] 1999) and was shared by many Romantics. Whilst most Romantics wrote Kunstmärchen intended for an adult public, the Grimms' tales were actually intended for children as well. In the foreword (Grimm \& Grimm 1812) the brothers emphasise the didactic value of the stories, so that they not only stemmed from an ancient childlike mentality, but were also presented as ideal children's literature concurring with bourgeois tendencies. But the very first readers already had grave objections: the Arnim family regarded the tales as utterly unsuitable for their children, as they contained clear sexual references and unbridled violence. Their criticism resonated. The Grimms had to reconsider their approach and revise the texts, so that the tales in the second volume (1815) were scrutinised, offensive passages removed or toned down, until they considered the volume safe as childfriendly literature. By the second edition in 1819 the tales had been completely subjected to acceptable bourgeois standards of morality and propriety of the time, in both plot and language.

The Grimms' poetics thus complied with the Romantic principles of purity and child-likeness. One must consider, though, that rendering the volumes child-friendly was really an act of defusing a literary genre that previously had been considered adult entertainment. Referring to the European fairy tale tradition, when the tales were an uncensored mirror of society where politics or sex were concerned, Ewers (2012) alleges that the Grimms single-handedly transformed 'the most erotic type of narrative genre' into 'an effective means of fleeing one's own sexuality - back to childhood' (Ewers 2012:64). It was still adults, not children, who read the Grimm fairy tales. But times had changed. The ideals of the Romantic Movement seemed to echo the needs of the individual. The intellectual 'discovery' of the child in the 19th century had little to do with the child per se. The idea was linked to repressed adult needs and desires of the times, as the sentimental reminiscing about a premodern past amidst fast scientific and technological advancement. People longed for simplicity in human relations in times of strife and hardship during political oppression, for metaphysical security in an increasingly secular world, for a naive belief in miracles and natural wonders and for the fascination of an existence beyond sexual drive (Ewers 2012). The Grimms' 'censored' fairy tales proved popular with a public wanting Romantic literature.

The opening tale in the 1812 first edition is The frog prince, the story in which a princess' favourite toy is rescued by a frog who at the end transforms into a handsome prince. From 1857 onwards the frog's transformation leads to a royal wedding with the King's blessing. This was not the case in the original. Here the prince promptly climbs into the princess' bed 'and both slept together happily' (Grimm \& Grimm 1812). Similarly, Rapunzel in later editions receives visits from the prince in the tower without being, as in the first edition, overpowered by him and subsequently struggling to fit into her clothes as her belly grows due to pregnancy. The sexual overtone inherent in many of the 1812 tales was removed or, as Ewers (2012:62) complains, 'heroes and heroines became younger and more childlike with each edition, sexual play was changed to children's play, and wedding feasts became children's parties. In short: they transformed erotic love and marriage stories into harmless child friendship stories'. At the very least, erotic encounters were replaced by proper marriages. Not only eroticism was censored; other crucial changes also took place. Current affairs were taken into account to provide a bridge between the old and the contemporary, such as the poverty of the family in Hänsel and Gretel that transforms into a period of famine from the fifth edition in 1843, referring 
to real events in the Alsace region. The role of the bad stepmother increasingly became a typecast whilst mothers and grandmothers became loving and caring, in tune with emerging bourgeois values. Previously it was none other than the biological mother or grandmother who performed the hideous deeds on their own children.

Many of these aspects have been singled out by psychologists and psychoanalysts and used to explain children's developmental stages. Bruno Bettelheim (1975) gave the Grimm fairy tales a special place in child psychology. His book remains a standard work. Bettelheim (1975), Zipes (2010) and others advocate that the 'old truths' of the 'people's tales' were astonishingly accurate in their educational and didactic messages. But they lacked popularity; they were not in tune with the much more 'civilized ways' of the bourgeois society of the time - as they are not in tune with ours today. Countless media versions for children, such as the Walt Disney movies, prove that the more uncomfortable aspects of life are still best avoided. In his recent work, psychoanalyst Eugen Drewermann (2012) reminds us of the many possible interpretations fairy tales can have, at various levels. According to his studies, fairy tales are not about rigid social parameters, but they rather offer a variety of personality types and basic problems they speak to all of us in some way (Drewermann 2012). He believes that although the Grimms might not even have fully realised the psychological depths and potential of their fairy tales, they were way ahead of their time. Zipes (2010) speaks of the persistence of fairy tales, of how they have developed as means of communication that enable us to grasp the problems that we have and provide ways to resolve them:

I liken the genre of fairy tales to a whale that ploughs through the ocean swallowing all the little fish that are around it, and it just becomes larger and larger. And in fact, the fairy tale is very difficult to define today because the genre encompasses film, internet, opera, musicals, photography, painting, illustrations, theatre, commercials - there are all types of fairy-tale forms that essentially show to what extent fairy tales stamp our lives on a daily basis. It has something to do with the fact that we are trying metaphorically to gain distance from our lives while at the same time to achieve some kind of happiness and meaning out of life. (n.p.)

There certainly is much to be said about the reasons why fairy tales remain so important throughout the world. The ancient stories of the people are probably indeed much more real than the public realises. Having fascinated generations, they appear to be enormously relevant for adapting to a rapidly changing world. The Grimms seem already to have known that. Educating the people according to high Romantic ideals has thus proven an endless task.

\section{In conclusion: Romantics but not quite}

None of the original fairy tales of 1812 remained untouched. Wilhelm revised and altered them continuously, in every one of the seven editions that appeared during their lifetime, changes were undertaken. Wilhelm, more than Jacob, understood the continuous flux of the tales as a means of making the 'voice of the people' as live, without crystallising the tales in a rigid literary form where they might petrify. He was the one more preoccupied with the literary, stylistic legacy which he did not want to be perceived as a static artistic creation. Jacob was interested in finding and maintaining the inherent truths of the tales and continued with scientific study and research. Whilst it is now acknowledged that it was owing to Wilhelm's particular and very unique narrative style that the tales embarked on their worldwide success story (Rölleke 2004), it can be concluded that the combination of the brothers' interests and talents brought about the distinctive poetics that may be Romantic in name but is not really Romantic in essence. The brothers took part in the Romantic Movement insofar as it suited their own cause but they disregarded its prescriptions: inspired by its political programme they followed parts of the philosophical programme but declined the poetic programme. With great confidence they went their own way so that their relationship with Romanticism can be seen as ambiguous at best.

As 'reluctant Romantics' the brothers encountered much resistance to their studies and were openly criticised by their peers:

Time and again they were disappointed. Their research on the history of language and literature, their analyses of legends, fairy tales and myths, their works on legal history, on manners and customs, or their politic activities were rarely appreciated in the way that they themselves considered appropriate. (Martus 2012:17)

Bound to each other in an unusual working commitment, they were guided by the principle of loyalty, the principle that defined their life and work, their research and their political views (Heidenreich \& Grothe 2009). According to Friemel (2012):

Around the middle of the 19th century, the Germanistik [German philology] was a science with a decidedly bourgeois, antidespotic, anticlerical and liberal engagement. All this also applies to the Brothers Grimm. (p. 36)

It can be argued that the political engagement, which was much more active, outspoken and consistent than most of their peers', was probably their most 'Romantic' trait. ${ }^{6}$

The Grimm's dedication to their work and to each other assured a unique albeit almost coincidental relationship to a movement with which they will be forever linked, but which they did not follow in their hearts. In spite or maybe because of that, German philology, German literature and German Romanticism would be unthinkable without their contributions. As for the fairy tales, no matter how

6.Their political engagement was a lifelong commitment, especially for Jacob, who took part in the Congress of Vienna (1814-1815) as a diplomat and who would take up a political position in the national assembly in Frankfurt in the politically crucial up a political position in the national assembly in Frankfurt in the politically crucial
year of 1848 . Their political stance was also made clear when they lectured whilst year of 1848 . Their political stance
lecturing in Göttingen in 1838. 
controversial their history and regardless of what modern times might do with them, they will continue to fascinate the Brothers Grimm made sure of that.

\section{Acknowledgements}

Competing interests

I declare that I have no financial or personal relationship(s) that may have inappropriately influenced me in writing this article.

\section{References}

Bettelheim, B., 1975, The uses of enchantment: The meaning and importance of fairy tales, Vintage Books/Ramden House, New York.

Bunzel, W. (ed.), 2010, Romantik: Epoche - Autoren - Werke, Wissenschaftliche Buchgesellschaft, Darmstadt.

Drewermann, E., 2012, Geschichten gelebter Menschlichkeit - oder: Wie Gott durch Grimm'sche Märchen geht, Patmos Verlag, Ostfildern.

Ewers, H.-H., 2012, 'Die Grimmsche Märchenkultur und der bürgerliche Kindheitskult des 19. Jahrhunderts', Zeit Geschichte 4(12), 58-65.

Friemel, B., 2012, 'Deutsche Sprache, deutsche Sagen: Die Grimms als Romantiker', Zeit Geschichte 4(12), 28-37.

Grimm, J., 1809, Briefwechsel (Brief an Wilhelm Grimm, 17. Mai 1809), Brüder Grimm Museum Online, Viewed 12 June 2013, from http://www.grimms.de/index. php?id=26\&lang=de\&site $=\% 2 F$

Grimm, J., [1808] 1985, 'Gedanken: Wie sich die Sagen zur Poesie und Geschichte verhalten', in L. Denecke (ed.), J. \& W. Grimm: Schriften und Reden, Reclam, Stuttgart.
Grimm, J. \& Grimm, W., 1812, Kinder- und Hausmärchen (KHM). (Jubiläumsausgabe mit Originalanmerkungen 1985), Reclam, Stuttgart.

Heidenreich, B. \& Grothe, E. (eds.), 2009, Die Grimms: Kultur und politik, SocietätsVerlag, Frankfurt am Main.

Herder, J.G., [1773] 1999, 'Auszug aus einem Briefwechsel über Oßian und die Lieder alter Völker' in H.D. Imscher (ed.), Herder/Goethe/Frisi/Möser: Von deutscher Art und Kunst, Reclam, Stuttgart.

Katzenstein, L., 1890-1895, Die Brüder Grimm bei der Märchenfrau, Museumslandschaft Hessen Kassel; bpk.

Martus, S., 2009, Die Brüder Grimm: Eine Biographie, Rowohlt, Berlin.

Martus, S. 2012, Die Lebensgeschichte Jacob und Wilhelm Grimms, Zeit Geschichte, $4(12), 14-25$.

Mende, C., 2002, Romantik, viewed 08 January 2014, from http://www. literaturwelt.com/epochen/romantik.htm

Rölleke, H., 2004, Die Märchen der Brüder Grimm. Eine Einführung, Reclam, Stuttgart.

Rölleke, H. (ed.), 2011, Es war einmal: Die wahren Märchen der Brüder Grimm und wer sie ihnen erzählte, Eichborn, Die Andere Bibliothek, Frankfurt am Main.

Rölleke, H., 2012, Volkspoesie? Von wegen! Woher die Kinder- und Hausmärchen in Wahrheit stammten, Zeit Geschichte 4(12), 38-45.

Rothmann, K., 1987, Kleine Geschichte der deutschen Literatur, Reclam, Stuttgart.

Schlegel, F., 1798, 116: 'Athenäum' - Fragment, Digitale Schule Bayern, viewed 12. June 2013, from http://www.digitale-schule-bayern.de/dsdaten/587/
903.pdf

Stephan, I., 2008, 'Kunstepoche', in W. Beutin (ed.), Deutsche Literaturgeschichte: Von den Anfängen bis zur Gegenwart, 185-240,' Metzler, Stuttgart.

Van Rinsum, W. \& Van Rinsum, A., 1987, Dichtung und Deutung. Eine Geschichte der deutschen Literatur in Beispielen, bsv, München.

Zipes, J., 1999, 'Breaking the Disney spell', in M. Tatar (ed.), The classic fairy tales, pp. 332-352, WW Norton, New York.

Zipes, J., 2010, Jack Zipes on fairy tales: Interview, viewed 12 September 2013, from http://fivebooks.com/interviews/jack-zipes-on-fairy-tales

Zipes, J., 2012, The irresistible fairy tale: The cultural and social history of a genre, Princeton University Press, Princeton. 